\title{
Fallopian Tube Germ Cell Tumor
}

National Cancer Institute

\section{Source}

National Cancer Institute. Fallopian Tube Germ Cell Tumor. NCI Thesaurus. Code C40130.

A rare germ cell tumor that affects the fallopian tube. The vast majority of cases are teratomas. 